\title{
Mellem drømme og mareridt - fremtidsudsigter for arbejdsmiljøets virkemidler
}

Nielsen, Klaus T.; Møller, Niels; Seim, Rikke; Limborg, Hans Jørgen ; Bramming, Pia

Published in:

Tidsskrift for Arbejdsliv

Publication date:

2016

Link back to DTU Orbit

Citation (APA):

Nielsen, K. T., Møller, N., Seim, R., Limborg, H. J., \& Bramming, P. (2016). Mellem drømme og mareridt fremtidsudsigter for arbejdsmiljøets virkemidler. Tidsskrift for Arbejdsliv, 18(1), 9-17.

\section{General rights}

Copyright and moral rights for the publications made accessible in the public portal are retained by the authors and/or other copyright owners and it is a condition of accessing publications that users recognise and abide by the legal requirements associated with these rights.

- Users may download and print one copy of any publication from the public portal for the purpose of private study or research.

- You may not further distribute the material or use it for any profit-making activity or commercial gain

- You may freely distribute the URL identifying the publication in the public portal

If you believe that this document breaches copyright please contact us providing details, and we will remove access to the work immediately and investigate your claim 


\title{
Kronik
}

\section{Mellem drømme og mareridt}

\section{- fremtidsudsigter for arbejdsmiljøets virkemidler}

\author{
Klaus T. Nielsen, Peter Hasle, Niels Møller, Rikke Seim, Hans Jørgen Limborg \& Pia Bramming
}

$\mathrm{D}$

en koordinerede arbejdsmiljøpolitiske indsats på nationalt niveau har været udviklet gennem en række planer; fra "Rent arbejdsmiljø 2005", lanceret af Arbejdstilsynet i 1996 til "En strategi for arbejdsmiljøindsatsen frem til 2020", som blev godkendt af den daværende regering i (2020-planen). På trods af planerne består den samfundsmæssige arbejdsmiljøindsats primært af mange relativt små ukoordinerede aktiviteter, som er præget af skiftende regeringers 'stop and go'-politik. Kort sagt er målene for fremtidens arbejdsmiljø høje, mens praksis synes utilstrækkelig for at opnå målene, og indsatserne gennemføres, selvom der er forbavsende lille viden om, hvordan de virker.

Både planer og praksis rejser spørgsmålet om, hvilke knapper man egentligt har at dreje på for at forbedre arbejdsmiljøet. "Virkemidler" tildeles da også stor opmærksomhed, fx i den rapport der udgjorde det faglige grundlag for 2020-planen (Arbejdstilsynet 2010) og i Arbejdsmiljøfondets forskningsstrategi.

Forskere fra en række forskningsmiljøer søgte derfor midler fra Arbejdsmiljøforskningsfonden og fik i 2011 bevilliget et større forskningsprogram: CAVI - Center for forskning i arbejdsmiljøindsatser og virkemidler. CAVI har overordnet beskæftiget sig med virkemidler og virksomhedernes reaktioner herpå.

Samtidigt med at 2020-planen blev udarbejdet, trådte ArbejdsMiljøOrganisationsreformen (AMO-reformen) i kraft. Det er den største ændring af virksomhedernes arbejdsmiljøaktiviteter siden arbejdsmiljøloven trådte i kraft i 1977, og samtidigt er AMO et af de vigtigste virkemidler i arbejdsmiljøindsatsen. AMO-reformen udgøres af de ændringer i reglerne om sikkerhedsarbejdets organisering på den enkelte arbejdsplads, der trådte i kraft i efteråret 2010, og som blandt andet ændrede betegnelsen 'sikkerhedsorganisation' til 'arbejdsmiljøorganisation', gjorde reglerne om hvornår der skal være en sikkerheds-/arbejdsmiljørepræsentant mere fleksible og indførte et krav om, at medlemmerne af arbejdsmiljøorganisationen skal tilbydes løbende, supplerende arbejdsmiljøuddannelse.

CAVI nærmer sig nu sin afslutning, blandt andet manifesteret ved nogle af artiklerne i dette temanummer af Tidsskrift for Arbejdsliv. Det er på grundlag af resultaterne fra dette program og dets delprojekter at vi - CAVI-programmets styregruppe - i denne 
kronik vil sætte nogle af de problemstillinger på spidsen, som i vores øjne træder frem i programmets forskning og resultater.

Vi har valgt at pege på tre områder, hvor vi har fået øje på betydningsfulde forhold, og inden for hvert af disse områder skitserer vi både et positivt-utopisk og et negativtdystopisk scenarie. På den måde spidsformulerer vi nogle af de dilemmaer, Danmark står overfor i udviklingen af arbejdsmiljøarbejdet og -politikken:

1. Den centrale rolle for ansatte arbejdsmiljøprofessionelle, som også får betydning for de valgte arbejdsmiljørepræsentanter.

2. Konsekvenserne af den stigende systemtænkning som vi fx finder i certificerede arbejdsmiljøsystemer.

3. Betydning af orkestrerede indsatser hvor flere virkemidler søges koordineret.

Da AMO-reformen blev gennemført med nye regler i 2010, var der både positive og negative forventninger til reformens effekter. På utopi-siden blev der peget på 1) de mere fleksible regler om selve organiseringen, 2) det løft af anerkendelsen af arbejdsmiljøarbejdet, der lå $\mathrm{i}$ selve navneskiftet og i forventningerne om et mere strategisk fokus i AMO og 3) især i det kompetenceløft, man håbede på med den supplerende uddannelse. Omvendt var der på dystopisiden bekymring for, at de fleksible regler betød væsentligt færre arbejdsmiljørepræsentanter, og at fraværet af tvungen efteruddannelse ville betyde, at der i praksis blev få, der fik mere uddannelse. Vurderet ud fra vores resultater og den evaluering som har været iværksat (Nielsen m.fl. 2014), er billedet noget mindre markant, end såvel utopi som dystopi kunne give anledning til at tro. Egentligt vil vi sætte spørgsmålstegn ved, om ordet "reform" overhovedet var passende. De fleste steder gjorde reformen ingen væsentlig forskel. Samtidigt indehol- der både dys- og utopi en slags sandhed, fordi de fleste af de ændringer, der er sket, ikke er initieret af reformen; men alligevel har resultatet typisk været, at man har udnyttet de fleksible regler til at reducere antallet af arbejdsmiljøgrupper. Således kan utopi/dystopi-figuren forhåbentligt være med til at tydeliggøre nogle af de aktuelle dilemmaer i arbejdsmiljøpolitikken.

\section{De arbejdsmiljøprofessionelle}

Det første område vi vil tage op, er den store betydning af professionelle i arbejdsmiljøindsatsen på arbejdspladserne. I AMOprojektet, der har været CAVI-programmets største delprojekt, blev der i projektets første runde undersøgt 60 større arbejdspladser. Et markant træk i mange af disse casevirksomheder har været tilstedeværelsen af en ansat arbejdsmiljøprofessionel. Vi har ikke haft snævert fokus på denne gruppe i projektet, men alligevel var denne gruppes store - og formodentligt stigende - betydning for det lokale arbejdsmiljøarbejde markant. De arbejdsmiljøprofessionelle bliver ansat (af ledelsen) til at være ansvarlige for organiseringen af arbejdsmiljøarbejdet, herunder at understøtte formelle systemer som arbejdsskadesregistrering og evt. certificeringssystemer, at organisere arbejdet i arbejdsmiljøorganisationen og at levere arbejdsmiljøfaglig ekspertbistand i mere konkrete sager. Man kan sige, at med AMOreformen afskaffede man det formelle krav om "daglig sikkerhedsleder", mens realiteten mange steder er blevet mere daglig "arbejdsmiljøledelse". Der er fællestræk i hele spektret fra de halvstore byggefirmaer (med måske 50 ansatte) til store omsorgsinstitutionsområder i kommuner og regioner (med over 500 ansatte). De mindre virksomheder var ikke omfattet af undersøgelsen, men der er næppe mange arbejdsmiljøprofessionelle. 
De arbejdsmiljøprofessionelles centrale rolle skal ses i relation til arbejdsmiljørepræsentanterne. I "den danske model" er medarbejderrepræsentanterne vigtige aktører i arbejdsmiljøarbejdet og inden for andre samarbejdsrelevante områder (Due m.fl. 1993). Modellen er her i tidsskriftet blandt andet blevet diskuteret og kritiseret af Knudsen \& Lind (2012) og Borchorst m.fl. (2012).

Dystopien er her, at de arbejdsmiljøprofessionelle reducerer betydningen af medarbejderrepræsentationen, og hermed bliver et vigtigt element i den danske model udhulet. Den danske model udpeger det dybt forankrede og konsensusbaserede forhandlingsspil mellem arbejdsgiverorganisationer og fagforeninger som rygraden i arbejdsmarkedets organisering. Staten har således en relativt tilbagetrukket rolle. Relationerne mellem parterne gentager sig så at sige på den enkelte arbejdsplads gennem forhandlinger og samarbejde mellem ledelse og medarbejdere/medarbejderrepræsentanter om løn, arbejdsforhold og andre forhold. På arbejdsmiljøområdet har man kopieret denne konstruktion, og arbejdsmiljøorganisationen har således haft et relativt ligeværdigt forhold mellem arbejdspladsens ledere og arbejdsmiljørepræsentanter. Nogle gange har det været medarbejdernes engagement som har været drivende, og andre gange har det været ledelsens ret til i sidste ende at tage beslutningerne, der satte dagsordenen; men dynamikken har været et interessebaseret repræsentationssystem, hvor parterne begge havde noget at skulle have sagt. De arbejdsmiljøprofessionelle kan i den sammenhæng risikere at komme til at fungere som en svamp, der suger energien ud af arbejdsmiljøorganisationen, flytter alle arbejdsmiljøaktiviteter over i ledelsen og retoucherer eventuelle interessekonflikter, så de ikke længere fremstår som modsætninger. I værste fald sidder den arbejdsmiljøprofessionelle i en stabsfunktion på ledelsens nåde, altså langt væk fra den daglige linjeledelse og uden tilstrækkelig selvstændig professionel legitimitet og indflydelse på arbejdsmiljøforholdene til at kunne gøre en forskel. Dermed svækkes et væsentligt element i den danske model, fordi et vigtigt område i praksis flyttes fra samarbejdets arena til ledelsens domæne.

Omvendt kan man pege på de positive potentialer, denne udvikling har. Tidligere var området præget af en række "amatører" (på både ledelses- og medarbejderside), der ovenikøbet var tilbøjelige til at småkævles mere end hvad godt var, fordi dette område var udpeget som et af de steder, hvor utilfredshed kunne luftes. Med det faglige løft, som de arbejdsmiljøprofessionelle udgør, tilføres feltet både viden og organiseringskapacitet, som betyder, at fokus kan flyttes til de væsentlige arbejdsmiljøforhold, og som gør, at der kan arbejdes systematisk, analytisk og måske også både medarbejderinddragende og strategisk. Når ledelsen først har fået øjnene op for de fordele der er ved at integrere arbejdsmiljøtankegange i andre ledelsesforhold, bliver arbejdsmiljøet håndteret langt mere betryggende og effektivt, når det gøres af en arbejdsmiljøprofessionel - som under alle omstændigheder er mere eller mindre afhængig af de ansattes erfaringer, ideer og engagement.

En sådan positiv udvikling ser vi primært, når de arbejdsmiljøprofessionelle også medvirker til at integrere arbejdsmiljøet i løsningen af kerneopgaven. Der er derfor ikke et enkeltstående billede af, hvordan rollen som intern arbejdsmiljøprofessionel udfyldes, men derimod en række forskellige, der afspejler arbejdspladsens måde at tænke styring, forebyggelse og udvikling på. Vi har i analysen af de tres AMO-cases identificeret tre markante tilgange til at udfylde rollen: 1) 'Systembyggeren', hvis opgave er at sætte arbejdsmiljøindsatsen ind i 
rammer, som afspejler den måde, man i øvrigt styrer kvalitet, miljøkrav, produktivitet $\mathrm{mm}$., som i mange produktionsvirksomheder er integreret i ledelsessystemer. 2) 'Den procesorienterede', der har fokus på at udvikle relationer og skabe organisatorisk ro, som det ofte bliver prioriteret på arbejdspladser, hvor der arbejdes med mennesker med fokus på omsorg, pleje, rehabilitering eller sundhed. 3) 'Den driftsorienterede', hvis vigtigste opgave er at sikre, at dårligt arbejdsmiljø ikke stiller sig som en hindring for at udføre arbejdet, enten gennem for stor risiko for ulykker og deraf følgende driftstab eller på grund af tabet, der opstår ved ikke at møde gældende regler eller fordringer fra kunder.

Der er mindst to vigtige diskussioner i forlængelse af ovenstående. Første diskussion hænger på, at det er vanskeligt at vurdere, hvad der fungerer bedst af de to muligheder: en god arbejdsmiljøorganisation eller en god arbejdsmiljøprofessionel? Eller kan vi pege på en relevant tredje vej: Et frugtbart samarbejde mellem AMO på den ene side, der forstår at arbejde strategisk og som formår at sikre, at medarbejderne bliver informerede og hørt, og arbejdsmiljøprofessionelle på den anden side, der har evnen til at omsætte strategierne til håndtering og forebyggelse, og som kender organisationen så godt, at de også formår at implementere arbejdsmiljøhensynet i den daglige praksis. Vi kan uden tvivl komme tættere på en vurdering heraf, hvis der blev gennemført mere forskning på området, men i den sidste ende er der tale om en politisk vurdering af betydningen af medarbejderinddragelse vs. professionel legitimitet.

Den anden diskussion tager udgangspunkt i, at udviklingen i et betydeligt omfang allerede har fundet sted, og at vi ikke kan vende den. Hvordan ser det ud med de professionelles betingelser for at fungere som professionelle? Klassisk set kan der peges på to aspekter, der konstituerer professionalitet: Viden og autonomi - eller sagt på anden vis: Hvilke uddannelsesforløb giver den professionelle retten til at udføre sin profession, og i hvilket omfang udøves professionen på den professionelles betingelser? I forhold til autonomien bliver spørgsmålet, om den professionelle egentligt har tilstrækkelig pondus i forhold til den ledelse, der har hyret vedkommende og kan der peges på måder, der kan styrke de professionelles uafhængighed? I forhold til viden og kompetencer er det interessant, om den arbejdsmiljøprofessionelle hovedsageligt bliver en, der kan vurdere arbejdsmiljøet og udpege de rette løsninger på de relevante problemer, eller om hun eller han bliver en person, som skal sikre at dokumentationssystemerne er etablerede og fungerer (der skal gennemføres trivselsundersøgelser, APV, årshjul, arbejdsskadesregistrering og -opfølgning, følges op på certificering og tilsynsbesøg m.m.). I forhold til uddannelsesforløbet må man stille spørgsmål ved, om vi har de rigtige uddannelsessystemer, der gør, at vi kan have tillid til at de professionelles faglighed - hvad enten den nu er af arbejdsmiljøfagligt tilsnit eller af mere systembyggende karakter. Efter vores vurdering er der behov (og mulighed) for at gentænke træning og uddannelse af de arbejdsmiljøprofessionelle. I øjeblikket har vi ingen anerkendte uddannelser for arbejdsmiljøprofessionelle i Danmark.

\section{Standarder, certificering og systemer $\mathrm{i}$ arbejdsmiljøarbejdet}

Arbejdsmiljøarbejdet i de fleste virksomheder har i mange år været præget af problemløsning. Man forsøger at løse de problemer i arbejdsmiljøet, som man på den ene eller anden måde blev opmærksomme på. Nu får arbejdsmiljøet i mange virksomheder efterhånden en plads som et indsatsfelt, der 
skal behandles på lige fod med alle andre problemstillinger, fx miljø, HR og kvalitet, og virksomheder begynder dermed at indføre systemer til at styre aktiviteterne. Det næste område vi tager op, knytter sig til de arbejdsmiljøledelsessystemer, som vi har kigget på i CERPA-delprojektet under CAVI (Hohnen m.fl. 2014). I det projekt er arbejdet med at få certificerede arbejdsmiljøledelsessystemer til at kunne håndtere det psykiske arbejdsmiljø blevet fulgt på kommunale arbejdspladser. Diskussionen vedrører dog ikke kun certificerede systemer, den handler også om, hvad selve systemkarakteren af indsatsen kan gøre ved arbejdsmiljøet, og dermed har problemstillingen også relevans andre steder, hvor man søger at gøre arbejdsmiljøarbejdet mere strømlinet og systematisk.

Her er utopien knyttet til det stærke tilvalg, der ligger i ledelsens engagement. Det er en relativ ambitiøs og omkostningsfuld (i hvert fald på den korte bane) løsning at skrue et ledelsessystem sammen, som siden skal certificeres af et eksternt certificeringsbureau med jævne mellemrum. Både de interne og de ekstern audits, som systemet kræver, fastholder hele tiden organisationens opmærksomhed på, om arbejdsmiljøledelsessystemet er aktivt. Herudover fastholder arbejdsmiljøledelsessystemet i sig selv de lokale lederes og medarbejderes opmærksomhed på arbejdsmiljøet på en systematisk måde, som gør, at man får taget hånd om alle relevante problemer.

Det psykiske arbejdsmiljø er imidlertid et problem for utopien, fordi det kniber med at få udviklet de ledelsesværktøjer, der muliggør et systematisk arbejde med psykisk arbejdsmiljø. Jo, vi har efterhånden udbredte trivselsmålinger eller noget, der ligner på rigtigt mange (af de større) arbejdspladser; men det kniber med opfølgning mange steder - hvordan sikrer man den systematiske opfølgning, når trivselsmålingerne viser dårlig trivsel på særlige områder? Problemet ligger dog i første omgang $i$, at systemerne på arbejdspladsen og i det omgivende samfund faktisk har svært ved overhovedet at tage det psykiske arbejdsmiljø alvorligt. Det er svært at måle og dokumentere, og der kan ikke udstikkes simple ledelsesinterventioner, der bare løser problemerne. Dermed bliver psykisk arbejdsmiljø svært at håndtere for både interne og eksterne auditører. Konkret viser det sig ved, at de eksterne auditører er utilbøjelige til at 'give afvigelser' på psykisk arbejdsmiljø, altså at udpege psykisk arbejdsmiljø som et problem. Mange steder fx i den kommunale sektor er man jo godt klar over, at det er her skoen trykker. Systematikken lover altså at fastholde opmærksomheden på de forhold, man kommer til at glemme, egentligt helst vil glemme og/eller ser bort fra, fordi man ikke rigtigt kan overskue dem, eller fordi de er tæt knyttet til ledelsens ret til at lede og fordele arbejdet. Det er dog ikke givet, at det faktisk er tilfældet. Systematikken kan være med til at fastholde opmærksomheden på 'besværlige problemer', men den kan også være med til, at man overser problemerne, som det er tilfældet, når det gælder psykisk arbejdsmiljø.

I værste fald kan den systematiske karakter af arbejdsmiljøarbejdet være med til at dræbe engagementet i arbejdsmiljøarbejdet lokalt. $\mathrm{Nu}$ er der jo alligevel et system, der tager sig af det, og hvis man involverer sig, skal man jo bare vedligeholde et 'system'. Den lokale ledelse kan føle sig nødsaget til at gøre deres, men uden medarbejdernes engagement. Vi har set det i en af vores større cases, hvor det hele tiden har været svært at involvere medarbejderne, men hvor en tiltagende forståelse af, at arbejdsmiljøsystemet i sidste ende er ledelsens ansvar, har ført til, at arbejdsmiljøorganisation nu er uden medarbejdernes engagement og gnist.

En anden relateret udvikling har vi set i 
omsorgsarbejde, hvor risikoen for vold fra borgere er et problem. I den klassiske forståelse af hvad det vil sige at være en professionel omsorgsmedarbejder inden for disse områder, er risikoen for vold en del af det job, man udfører. En uønsket men uundgåelig del af arbejdet, når man fx arbejder med demente borgere. Arbejdets kerne er relationen til borgeren, og volden er en del af denne relation. Derfor er professionel adfærd en adfærd, hvor man i sin omgang med borgeren er opmærksom på risikoen. I samspillet med borgeren forsøger man at minimere risikoen ved at være opmærksom på borgerens signaler, ved at trappe den anspændte situation ned og ved om nødvendigt tage andre forholdsregler som $\mathrm{fx}$ at være to tilstede. Mange steder har man imidlertid indført en systemlogik, der formuleres som nul-tolerance, og hvor den enkelte borger systematisk skal monitoreres ved brug af obligatoriske tjeklister. Flere steder kunne personalet ikke få de nu obligatoriske personlige alarmsystemer, man hele tiden skal have på sig, til at 'virke' rent teknisk. Vi fortolker det som modstand fra personalet side. De oplever forandringerne som faste regler og procedurer, der gennemføres på bekostning af deres faglige pædagogiske autonomi. Den centrale forskydning er, at borgernes adfærd flyttes fra at være et indre aspekt af omsorgsarbejdet til noget uønsket, om end en uundgåelig del af arbejdet. Systemet betyder, at problemet objektiveres og flyttes ud ad den professionelle sfære og selvforståelse. Volden gøres til noget systemet kan håndtere, samtidig med at der bliver ved med at forekomme vold - om end ikke nødvendigvis i det samme omfang og med lige så alvorlige konsekvenser.

Vores dystopi i forhold til denne diskussion handler altså om systemkarakteren, som vi finder både i de certificerede systemer og i nogle af de systemer, som de arbejdsmiljøprofessionelle udvikler i deres praksis. Der skal være opmærksomhed - også systematisk opmærksomhed - på de arbejdsmiljøforhold, som findes på arbejdspladsen. Voldsrisikoen i omsorgsarbejdet er et stort og reelt problem, som der skal arbejdes seriøst med. Vi vil dog også pege på risikoen for at tingene kan blive så overorganiserede, at almindelige medarbejdere ikke føler, der er plads til dem, hverken som arbejdsmiljøengagerede eller som professionelle omsorgsarbejdere, hvis arbejde er relationer til de borgere, der nogle gange er udadreagerende.

\section{Orkestrerede indsatser - om at spille sammen}

Vi har som anført haft arbejdsmiljøplaner siden 1990'erne, og planerne har alle gange udpeget særlige fokusområder, som de forskellige aktører og deres indsatser skulle rettes mod for at indfri de ofte ganske ambitiøse mål, der gjaldt for fokusområderne. Tankegangen bag sådanne planer er, at hvis man opstiller klare, fokuserede og forpligtigende mål, er det også muligt at målrette indsatsen og dermed skabe arbejdsmiljømæssig udvikling, især på de udvalgte områder. Man har imidlertid sjældent nået målene, men oftest klappet sig selv på skuldrene og sagt, at det da gik i den rigtige retning (se fx Arbejdstilsynet 2007).

Med det dystopiske blik er det naivt eller ligefrem selvbedragerisk at tro, at sådanne planer berettiger de mange faglige og politiske ressourcer, der bliver lagt i at få planerne etableret. Man flytter blikket fra de umiddelbare handlinger til fordel for en intens opmærksomhed på, hvilke problemer der skal udråbes til den næste planperiodes indsatsområder. Den politiske dagsorden handler meget om mål og for lidt om, hvad der skal til for at nå målene. Når målene er udråbt, så læner man sig tilbage og venter på, at den fokuserede indsats skal virke, evaluerer lidt undervejs, og når man nær- 
mer sig målstregen, skal man udvikle en ny plan. Desværre er en samlet evaluering af den foregående periode ikke klar, så de nye mål bliver formuleret lidt i blinde. I dette perspektiv er planers målsætninger for meget præget af politik og tilfældigheder, de gennemførte indsatser er i bedste fald additive, men yderst sjældent egentligt synergiske. Målsætningerne nås stort set aldrig, og de udvalgte problemstillinger trækker opmærksomhed væk fra det, der ikke lige står i planen.

Omvendt skal man ikke overse betydningen af den faglige og politiske opmærksomhed på arbejdsmiljøet og de områder, der udpeges som væsentlige. Man kan sige, at virkningen af planerne ikke er en effekt af indsatserne som sådan; men at en manglende opmærksomhed ville have langt større negative konsekvenser. Man kan sige, at virkningen af planerne ikke er en effekt af indsatserne som sådan, men at en manglende opmærksomhed ville have langt større negative konsekvenser. Det kan sammenlignes med kampagner, det sigter på at få folk til at køre med sikkerhedssele. Kampagnen ændrer næsten ikke ved, hvor mange der kører med sikkerhedssele - virkningen er derimod at undgå, at nogle bilister holder op med at bruge sikkerhedssele igen.

Hvis vi så tager de utopiske briller på, tegner der sig konturerne af forspildte muligheder. Det vi har brug for er ikke mindre plan og koordinering. Realiteten hidtil er, at forsøget på en orkestrering kun er nået til, at alle spiller næsten den samme melodi. Problemet er blot, at de ikke spiller i samme orkester. Hvad hvis man spillede den samme melodi, på samme tid og i samme orkester? Der ville åbne sig helt nye muligheder, hvis man faktisk spiller sammen.

I INVINE-projektet, der er et af CAVIprogrammets projekter, har vi fulgt tre arbejdsmiljørelaterede netværk, og i forbin- delse med de to netværk, der har handlet om manuel håndtering og udvikling af hjælpemidler i henholdsvis små mejerier og mikrobryggerier, har vi set betydningen af samspillet af de mange virkemidler. Der var et vist pres fra Arbejdstilsynet på, at en indsats var påkrævet, der var mulighed for støtte til faglig konsulentbistand og siden til selve teknologiudviklingen, og der var et godt samarbejde mellem de forskellige arbejdsgivere i branchen. Det kneb ganske vist efterfølgende med at få de udviklede redskaber taget i brug i dagligdagen, men trods alt er erfaringerne fra casene, at det er de mange samtidigt tilstedeværende betingelser og muligheder, der skaber udvikling lokalt. (Limborg \& Grøn 2014)

Et andet eksempel på betydningen af et positivt samspil mellem forskellige virkemidler har vi fundet i maskinindustrien. I 2006 annoncerede Arbejdstilsynet, at screeningen af industrien ville foregå i 2007 (jf. den daværende Arbejdsmiljølov, som foreskrev at alle arbejdspladser skulle screenes inden for syv år). Det gav anledning til, at BAR-industri introducerede deres såkaldte 'roadshow', hvor man tog rundt i landet og diskuterede med virksomhederne (ofte mødte en leder og en arbejdsmiljørepræsentant frem sammen) hvad screeningen betød, og hvad man kunne gøre for at forberede sig, så man ikke fik problemer med Arbejdstilsynet. Kombinationen af Arbejdstilsynet og Branchearbejdsmiljørådet gjorde 'roadshows'ene' til en forrygende succes, og man har årligt gennemført dem siden, selvom screeningerne for længst er gennemført. Sidenhen har der været lignende indsatser i de brancher, hvor man har gennemført det såkaldte særlige tilsyn; men den tilsynsform er nu forsvundet som en konsekvens af den seneste finanslov.

Pointen er, at det politiske og arbejdsmiljøfaglige felt typisk tænker og udvikler virkemidlerne adskilte og knyttet til spe- 
cifikke påvirkningsmuligheder og aktører, som ikke sammentænkes. Derimod ser arbejdspladserne virkemidlerne som forskellige aspekter i et samlet landskab - eller for at blive i orkestermetaforen, så er det vigtigste ved musikken ikke de enkelte stemmer eller instrumenter, men det samlede indtryk de skaber for lytteren.

Spørgsmålet er således, om det er praktisk og politisk muligt at udvikle de samspilseffekter, som eksemplerne her kan tages til indtægt for, eller om erfaringerne omvendt taler for, at det ikke kan lade sig gøre på grund af de praktiske og politiske vanskeligheder, der er knyttet til at etablere et synergiskabende samspil mellem Arbejdstilsyn, arbejdsmarkedets parter og de forskellige øvrige aktører (primært branchearbejdsmiljøråd, rådgivere og forskning). Var det muligt, kunne der udvikles et koordineret samspil, hvor der indgår både pisk, gulerod og prædiken, som er populære benævnelser for de forskellige virkemidler, vi som samfund har til rådighed (Hasle m.fl. 2014).

\section{Afsluttende bemærkninger}

Vi slutter med kommentarer til to forhold, som i en vis forstand ligger i hver sin ende af det spektrum, der spændes ud mellem forskning og politik på arbejdsmiljøområdet. Først siger vi noget om, hvad forskningen kan og ikke kan i forhold til arbejdsmiljøpolitikken, siden bekymrer vi os for, om arbejdsmiljøindsatsen for øjeblikket i for høj grad er præget af 'hovsa'-løsninger.

Undervejs i forløbet har de fleste af os været involveret i en række workshops arrangeret af Arbejdsmiljørådet om evaluering på arbejdsmiljøområdet. På arbejdsmiljøområdet, som på så mange andre områder, er interessen for en mere evidensbaseret indsat voksende. Som tidligere nævnt er der også en stor interesse for virkemidler i forbindelse med bl.a. arbejdsmiljøplaner- ne; en interesse, som også udspringer af et ønske om at kunne bruge forskningen herunder vores forskning - til at optimere indsatserne. Inden for programmets egne rækker har vi diskuteret muligheder og begrænsninger, når det gælder mulighederne for at imødekomme denne legitime instrumentelle interesse. Det er desværre ikke muligt at komme med entydige evidensbaserede meldinger om, hvordan arbejdsmiljøpolitikken bør indrettes. Tværtimod er vores budskab, at koblingerne mellem arbejdsmiljøpolitikken og dens virkemidler på den ene side og arbejdspladsernes afkodning af arbejdsmiljøpolitikkens krav og budskaber på den anden, er afhængige af mange betingelser, dynamikker og forståelser. Hverken tal eller teori kan derfor gøre sig håb om at bibringe simple bud på, hvordan man styrker arbejdsmiljøindsatsen og forbedrer arbejdsmiljøet. Vi kan håbe at forskningen kan bidrage til et mere oplyst og reflekteret grundlag for de mange og varierede indsatser, der er nødvendige for at sikre og udvikle et sundt arbejdsmiljø.

Vores bekymring for urealistiske ambitioner om evidensbaseret indsatser $\mathrm{i}$ arbejdsmiljøet, overskygges af vores bekymring for den 'stop-and-go'-politik, som vi ser i øjeblikket, og som hverken respekterer institutioner, erfaringer eller er baseret på forskning eller evidens. Arbejdstilsynet har været i gang med at videreudvikle de såkaldte særlige tilsynsindsatser, i forhold til bl.a. psykisk arbejdsmiljø; men det stoppes nu, fordi Arbejdstilsynet beskæres. Tidligere nedlagde man Bedriftssundhedstjenesten og erstattede den med Forebyggelsesfonden, som man så siden amputerede og her til sidst lukkede. Branchearbejdsmiljørådenes økonomiske situation har været usikker i en længere periode, og det giver naturligvis usikkerhed i systemet. Alt $i$ alt mener vi, at man spiller hasard ved at implementere 'hovsa'-løsninger, som har uoverskuelige 
og uforudsigelige konsekvenser. Tidligere, da man i USA havde den første bølge af tiltro til evidensbaserede politik - det var i 1960'erne, da Johnson var præsident (Krogstrup 2011) - talte man om et "experimental society", hvor man, når det gjaldt sociale reformer, tænkte dem som eksperi- menter, man skulle opsamle data fra. Man dokumenterede systematisk eksperimenter, og på dette veldokumenterede grundlag justerede man reformerne. Vi synes, at dette kunne være et ideal for en mere forskningsbaseret tilgang til forandringer og reformer på arbejdsmiljøområdet.

\section{REFERENCER}

Arbejdstilsynet (2007): 10 år med handlingsprogrammet 'Rent arbejdsmiljø 2005', Arbejdstilsynet.

Arbejdstilsynet (2010): Fremtidens arbejdsmiljø 2020 - fagligt grundlag for prioritering af arbejdsmiljøindsatsen, Arbejdstilsynet.

Borchorst, A., E. Caraker \& H. Jørgensen (2012): Den danske model i knibe - også for analytisk potentiale? i Tidsskrift for Arbejdsliv, 14, 2, 82-104.

Due, J., J.S. Madsen \& C.S. Jensen (1993): Den danske model - En historisk sociologisk analyse af det kollektive aftalesystem, København, Jurist- og Økonomforbundets Forlag.

Hasle, P., H.J. Limborg \& K.T. Nielsen (2014): Working environment interventions Bridging the gap between policy instruments and practice, i Safety Science, 68, 73-80.

Hohnen, P. m.fl. (2014): Hard work in soft regulation - A discussion of the social mecha- nisms in OHS management standards and possible dilemmas in the regulation of psychosocial work environment, i Nordic Journal of Working Life Studies, 4, 3, 13-30. Knudsen, H. \& J. Lind (2012): De danske modeller - Plus ca change, plus c'est la même chose? i Tidsskrift for Arbejdsliv, 14, 2, 9-30.

Krogstrup, H.K. (2011): Kampen om evidens Resultatmåling, effektevaluering og evidens, København, Hans Reitzels Forlag.

Limborg, H.J. \& S. Grøn (2014): Networks as a Policy Instrument for Smaller Companies, i Nordic Journal of Working Life Studies, 4, 3, 53-55.

Nielsen, H.O. m.fl. (2014): Evaluering af samarbejdet om arbejdsmiljø $i$ virksomheder (AMO) - Hovedrapport, Oxford Research: (http:// arbejdstilsynet.dk/ /media/at/at/16-omarbejdstilsynet/09-publikationer-om-arbejdstilsynet/amo-evaluering2014/hovedrapport\%20endelig\%20pdf.ashx)

Klaus T. Nielsen, Peter Hasle, Niels Møller, Rikke Seim, Hans Jørgen Limborg \& Pia Bramming udgør CAVI-programmets styregruppe 